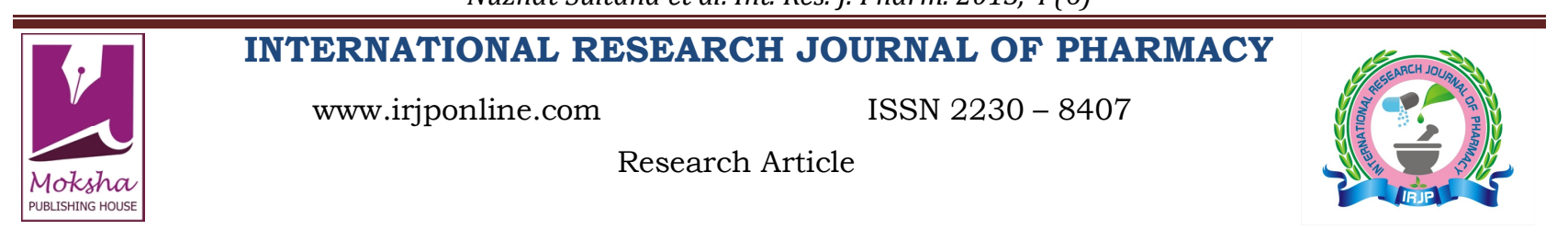

\title{
ANTI-TUSSIVE EFFECT AND GROSS TOXICITIES OF METHANOL EXTRACT OF MUCUNA PRURIENS (L) DC IN COMPARISON OF CODEINE PHOSPHATE
}

\author{
Nuzhat Sultana ${ }^{1}$, Rafeeq Alam Khan ${ }^{1}$, Iqbal Azhar ${ }^{2}$ \\ ${ }^{1}$ Department of Pharmacology, Faculty of Pharmacy, University of Karachi, Karachi, Pakistan \\ ${ }^{2}$ Department of Pharmacognosy, Faculty of Pharmacy, University of Karachi, Karachi, Pakistan \\ *Corresponding Author Email: nuztsultana@gmail.com
}

Article Received on: 12/03/13 Revised on: 11/04/13 Approved for publication: 10/05/13

DOI: $10.7897 / 2230-8407.04614$

IRJP is an official publication of Moksha Publishing House. Website: www.mokshaph.com

(C) All rights reserved.

\section{ABSTRACT}

The aim of the current study is to evaluation of plant seed extract of Mucuna pruriens for its gross toxicities and antitussive activity. Anti-tussive effect was observed by inducing cough using sulfur dioxide gas and counts the number of cough before and after administration of extract and centrally acting cough suppressant (codeine phosphate) given orally. Mucuna pruriens seed extract showed highly significant antitussive effect $(* *$ p $<0.005)$ and compare to control and reference drug codeine phosphate and may act on opioid receptor that may located in airway passage and produces inhibitory effect. The results suggest that Mucuna pruriens seed may contains cough protective agent and have potential therapeutic value.

Keywords: Anti-tussive effect, gross toxicities, codeine phosphate, mice, Mucuna pruriens.

\section{INTRODUCTION}

Treatment with the herbal medicines is not new they are used from thousands of years ${ }^{1}$. Total flowering plants are approx. 4, 22,000 from which 50,000 have medicinal values ${ }^{2}$.

In under developed countries traditional herbal drugs have a great demand due to their lesser adverse effects, efficacy and low cost ${ }^{3}$ and for biological and pharmacological assessment at least $20 \%$ of plants are used ${ }^{4}$ and they play an important role in the cure of respiratory diseases but clinical trials are required to assess the role of medicinal herbs. In developing countries $80 \%$ of people depend on natural products especially from plants for their health issues ${ }^{5}$.

Herbal medicines have major role for prevention and treatment of diseases ${ }^{6}$ in various ancient traditional system of medication, despite advances in modern pharmaceutical medicines, herbal drugs still play an important in preventive and curative of diseases. Commercially medicinal plants are cultivated for extraction of some important active constituents. Furthermore, active constituents give better result when it combines with other constituents ${ }^{7}$.

Mucuna pruriens (L) DC family Fabaceae, is a climbing legume $^{8}$ and well-known plant in ancient practices 9 commonly known as Kapikachu or Velvet bean widely distributed in Pakistan, India, Sri Lanka, Burma, Africa ${ }^{10}$. The plant is $15 \mathrm{~m}$ in length, climbing and annual shrub. Seeds are shiny black or brown. Young plant is completely covered with hairs and when older, hairs are completely removed. Seedpods are covered with loose orange hairs that are responsible for severe itch ${ }^{9}$. Hair of the Mucuna pruriens contains 5-hydroxytryptamine, protein and mucunain ${ }^{11}$ that causes severe itching. Other constituents of Mucuna pruriens are L-DOPA ${ }^{10}$ crude protein, 20-29\%, niacin, nicotine, total dietary fibre $8-10 \%$, crude fat, ash $3 \%$, carbohydrates 50 $60 \%$, valine, cystine, methionine, threonine, tryptophan, tryptamine, tyrosine, vernolic acid, water, leucine, oleic acid, linoleic acid, palmitic acid, trypsin, saponins, riboflavin and flavonoids.

Plant used in the treatment of Parkinson's disease ${ }^{12}$ because seeds contain high concentration of levodopa i.e a direct precursor of the neurotransmitter dopamine ${ }^{13}$. The hairs of the plant are used as vermifuge (Krishnan, 2000). In infertile men Plant seeds are helpful to increase the sperm concentration and motility ${ }^{14}$. It has anti-anaemic ${ }^{8}$, antifungal $^{15}$, anthelmintic ${ }^{11}$, anti-protozoal ${ }^{16}$, anti-microbial ${ }^{11}$, anti-diabetic ${ }^{17}$ neuroprotective $e^{13}, \quad$ antioxidant $^{18}$, hypocholeterolemic $^{19}$, aphrodisiac ${ }^{20}$ and hypoglycemia properties $^{21}$. In addition, it has a prophylactic activity in snakebite $^{22}$ and helpful against cobra venom-induced cardiotoxicity ${ }^{23}$ and, cough and cold. Body takes to get rid of substances that are responsible to irritating the air passages is a cough. In acute cough that may be 15- 20 days can be caused by an infection and noninfectious include pneumonia, viral upper respiratory infections, whooping cough and acute bronchitis $^{24}$ and chronic cough that is more than 20 days $^{25}$. Chronic cough may be due to conditions within the lungs, environmental irritants, chest cavity conditions or condition of the passages that transmit air.

\section{MATERIALS AND MATHODS \\ Extract Preparation}

The seeds of Mucuna pruriens were collected from the month of May and soaked in methanol for ten days. The methanol was filtered and the extract was concentrated by means of evaporation, thick gummy mass was collected. The concentrated mass of Mucuna pruriens seeds was used for antitussive activity and gross toxicities.

\section{Animals Selection}

Albino mice (25-30 gm) of both sex were used and maintained at $22 \pm 1{ }^{\circ} \mathrm{C}$ with light/ dark cycle of twelve/ twelve hours or from 08.00 a.m to 08.00 p.m at the Department of Pharmacology, University of Karachi. They were housed two per cage in under standard environmental conditions and kept at least $4-5$ days before start of experiment.

\section{Dosing}

The animals were divided into five groups $(n=7)$. One group served as control group received saline $0.9 \%$, three groups of seed extract of Mucuna pruriens in the doses of 300, 500 and $1000 \mathrm{mg} / \mathrm{kg}$ and last group received standard drug codeine phosphate $(10 \mathrm{mg} / \mathrm{kg})$. 


\section{Assessment of Gross Toxicity}

The gross toxicities were assessed on weekly basis for 30 days and noticing awareness, alertness, stereotype, mood, vocalization, aggression, tremors, spontaneous activity, fearfulness, corneal reflex, light reflex, touch response, body movement, pain response, sedation, grip strength, body tone, limb tone, passivity, irritability, piloerection, staggering gait, startle response and note the number of animals died during the total period of experiment.

\section{Antitussive activity}

Antitussive activity of plant extract was determined by using a sulfur dioxide gas-induced cough in mice ${ }^{26}$. During experiment concentrated sulfuric acid and aqueous saturated sodium hydrogen sulfite solution were introduced in apparatus to produce the sulfur dioxide gas and pressure of gas recorded by mercury manometer.
Initially, at 0 minute the cough response of all the groups was observed by placing the animals in sulfur dioxide gasinduced cough apparatus one by one. Animal was taken out from the apparatus after one minute of introducing the gas. Frequency of cough was observed for five minutes. In the same way the frequency of cough before drug administration were observed for all the animal groups at 0 minutes and after drug administration at 30, 60, 90 and 120 minutes intervals.

\section{Statistical Analysis}

All results were expressed as average value \pm standard deviation (St.Dev). The significance of difference between averages was determined ${ }^{27-28}$. The data obtained from present study was analyzed for P-value $<0.05$ was considered as significant and $\mathrm{P}$-value $<0.005$ was considered as highly significant, following the one way ANOVA.

Table 1: Gross Behavioral Activities

\begin{tabular}{|c|c|c|c|c|c|c|c|c|c|c|c|c|}
\hline \multirow[t]{2}{*}{ Activities } & \multicolumn{3}{|c|}{ Increase (Days) } & \multicolumn{3}{|c|}{ Decrease (Days) } & \multicolumn{3}{|c|}{ No Change (Days) } & \multicolumn{3}{|c|}{ Present/Absent (Days) } \\
\hline & 07 & 15 & 30 & 07 & 15 & 30 & 07 & 15 & 30 & 07 & 15 & 30 \\
\hline Awareness & - & - & - & $* \downarrow$ & $* \downarrow$ & $* \downarrow$ & - & - & - & - & - & - \\
\hline Alertness & - & - & - & $* \downarrow$ & $* \downarrow$ & $* \downarrow$ & - & - & - & - & - & - \\
\hline Stereotype & - & - & - & - & - & - & NIL & NIL & NIL & - & - & - \\
\hline Mood & - & - & - & $* \downarrow$ & $* \downarrow$ & $* \downarrow$ & - & - & - & - & - & - \\
\hline Vocalization, & - & - & - & - & - & - & NIL & NIL & NIL & - & - & - \\
\hline Aggression & - & - & - & - & - & - & NIL & NIL & NIL & - & - & - \\
\hline Tremors & - & - & - & - & - & - & NIL & NIL & NIL & - & - & - \\
\hline Spontaneous activity & - & - & - & $* \downarrow$ & $* \downarrow$ & $* \downarrow$ & - & - & - & - & - & - \\
\hline Fearfulness & - & - & - & - & - & - & - & - & - & -ve & -ve & -ve \\
\hline Corneal reflex & - & - & - & - & - & - & NIL & NIL & NIL & - & - & - \\
\hline Light reflex & - & - & - & - & - & - & NIL & NIL & NIL & - & - & - \\
\hline Touch response & - & - & - & $* \downarrow$ & $* \downarrow$ & $* \downarrow$ & - & - & - & - & - & - \\
\hline Body Movement & - & - & - & $* \downarrow$ & $* \downarrow$ & $* \downarrow$ & - & - & - & - & - & - \\
\hline Pain response & - & - & - & $* \downarrow$ & $* \downarrow$ & $* \downarrow$ & - & - & - & - & - & - \\
\hline Sedation & - & - & - & - & - & - & - & - & - & $+\mathrm{ve}$ & + ve & $+\mathrm{ve}$ \\
\hline Grip Strength & - & - & - & $* \downarrow$ & $* \downarrow$ & $* \downarrow$ & - & - & - & - & - & - \\
\hline Body tone & - & - & - & $* \downarrow$ & $* \downarrow$ & $* \downarrow$ & - & - & - & - & - & - \\
\hline Limb tone & - & - & - & $* \downarrow$ & $* \downarrow$ & $* \downarrow$ & - & - & - & - & - & - \\
\hline Passivity & - & - & - & - & - & - & - & - & - & $+\mathrm{ve}$ & $+\mathrm{ve}$ & $+\mathrm{ve}$ \\
\hline Irritability & - & - & - & - & - & - & - & - & - & -ve & -ve & -ve \\
\hline Piloerection & - & - & - & - & - & - & - & - & - & -ve & -ve & -ve \\
\hline Staggering Gait & - & - & - & - & - & - & - & - & - & -ve & -ve & -ve \\
\hline Startle response & - & - & - & - & - & - & - & - & - & -ve & -ve & -ve \\
\hline
\end{tabular}

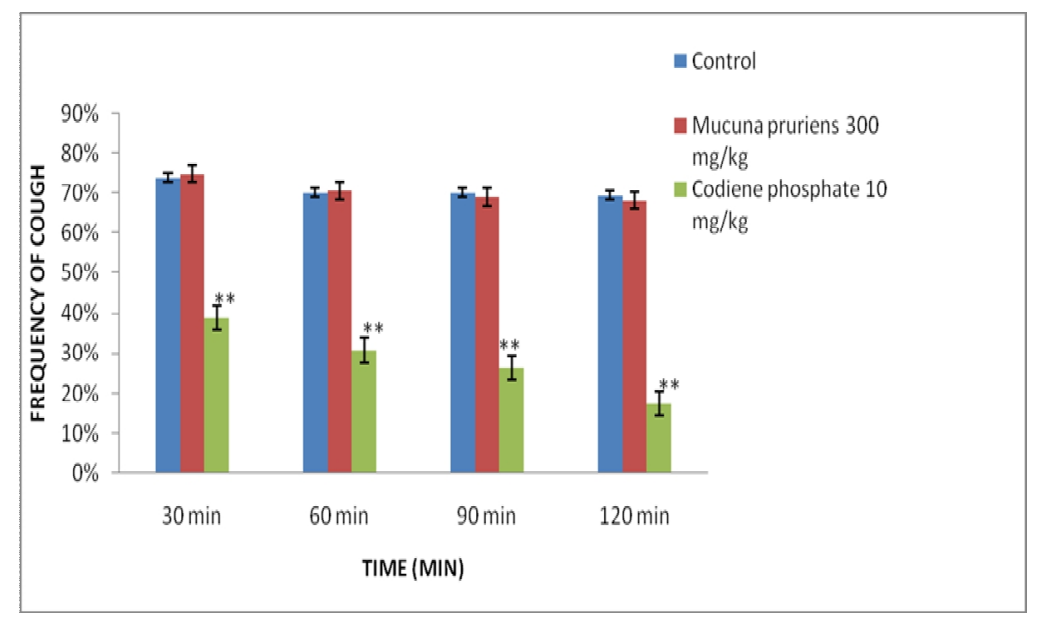

Figure 1: Effect of Mucuna pruriens at the dose of $300 \mathrm{mg} / \mathrm{kg}$

$\mathrm{n}=7$, Average value \pm St. Dev; Significant difference by Newman Keuls test; ${ }^{* *} \mathrm{p}<0.005$ as compared to control rabbits, following one way ANOVA 


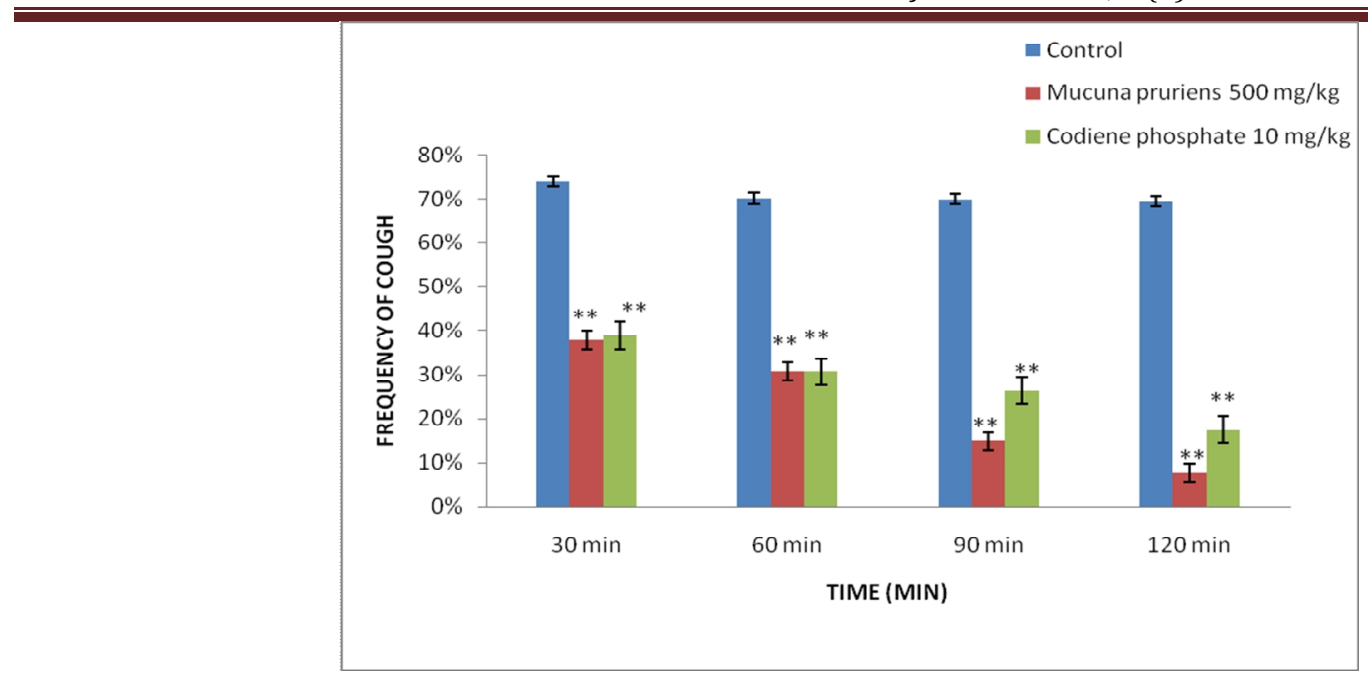

Figure 2: Effect of Mucuna pruriens at the dose of $500 \mathrm{mg} / \mathrm{kg}$

$\mathrm{n}=7$, Average value \pm St. Dev; Significant difference by Newman Keuls test; $* * \mathrm{p}<0.005$ as compared to control rabbits, following one way ANOVA

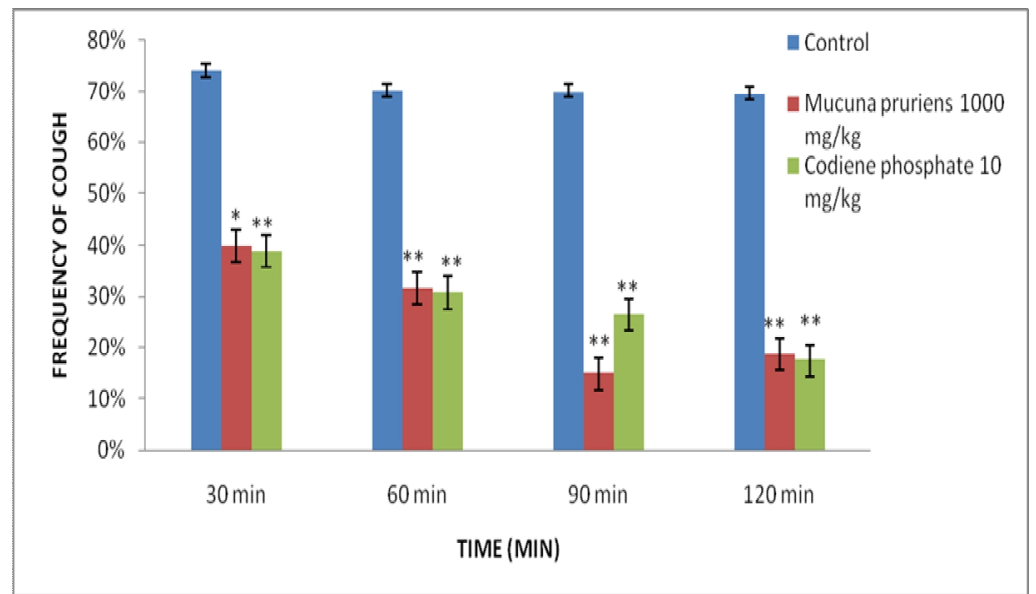

Figure 3: Effect of Mucuna pruriens at the dose of $1000 \mathrm{mg} / \mathrm{kg}$

$\mathrm{n}=7$, Average value \pm St. Dev; Significant difference by Newman Keuls test; ${ }^{*} \mathrm{p}<0.05$ as compared to control; $* * \mathrm{p}<0.005$ as compared to control rabbits, following one way ANOVA

\section{RESULS}

\section{Assessment of Gross Toxicities}

No gross toxicity was observed in any group of animals during the total period of experiment. Animals showed significant $(* p<0.05)$ reduction in pain response, grip strength, body tone, limb tone, awareness and alertness with significant $(* \mathrm{p}<0.05)$ increase in sedation during the total period of experiment and showed significant $\left({ }^{*} \mathrm{p}<0.05\right)$ increase in passivity with no significant change in righting reflex after administration of Mucuna pruriens (Table 1) and no death occur during the total period of experiment.

\section{Antitussive activity}

Mucuna pruriens extract (300, 500 and $1000 \mathrm{mg} / \mathrm{kg}$ ) showed significant cough suppressive activity. No cough suppressive effect was seen at the dose of $300 \mathrm{mg} / \mathrm{kg}$ with percentage inhibition of $75.0 \%$ (at $30 \mathrm{~min}$ ), $70.60 \%$ (at $60 \mathrm{~min}$ ), $69.0 \%$ (at $90 \mathrm{~min}$ ), and $68.30 \%$ (at $120 \mathrm{~min}$ ) in Figure 1.

It showed marked cough suppressive activity at $500 \mathrm{mg} / \mathrm{kg}$ with percentage inhibition $37.9 \%$ (at $30 \mathrm{~min}$ ), $30.7 \%$ (at 60 min), $14.9 \%$ (at $90 \mathrm{~min}$ ), and $7.7 \%$ (at $120 \mathrm{~min}$ ) in Figure 2. Results were obtained at $1000 \mathrm{mg} / \mathrm{kg}$ with percentage inhibition $39.90 \%$ (at $30 \mathrm{~min}$ ), $31.70 \%$ (at $60 \mathrm{~min}$ ), $15 \%$ (at $90 \mathrm{~min}$ ), and $18.70 \%$ (at $120 \mathrm{~min}$ ) in Figure 3.
Codeine phosphate produced $38.7 \%$ (at $30 \mathrm{~min}$ ), 30.7 (at 60 $\mathrm{min}$ ), $26.4 \%$ (at $90 \mathrm{~min}$ ) and $17.5 \%$ (at $120 \mathrm{~min}$ ) inhibition of cough frequency in animals. The comparison of the antitussive effect of Codeine phosphate and time interval is shown in Figures 1-3.

\section{DISCUSSION}

Herbal drugs have potential source of therapeutics and help in health care system for human beings all over the world. And further research of medicinal herbs is necessary to isolate the active compounds responsible for the biological activities ${ }^{5}$. Mucuna pruriens was selected for present study because of its medicinal value and some previous research studies such as seeds are used as alternative to L-DOPA and relieve pain and fever ${ }^{29}$.

In gross toxicities, animals showed no significant change in corneal reflex, light reflex, tremor and animals became passive after administration of Mucuna pruriens at the dose of $500 \mathrm{mg} / \mathrm{kg}$. It was also noted that the plant seed extract is affected on pain and touch responses. It significantly reduces $\left({ }^{*} \mathrm{p}<0.05\right)$ the touch response and body movement with significant reduction $\left({ }^{*} \mathrm{p}<0.05\right)$ in awareness, alertness, and locomotion. It also significantly reduces $(* \mathrm{p}<0.05)$ the grip strength and body tone, it could be due to the deficit motor 
coordination and muscle tone occurred during administration of Mucuna pruriens.

In gross toxicity tests plant seed extract showed sedation and decrease pain and grip strength may indicated its cough suppressive effect and extract of Mucuna pruriens seeds has been reported to be useful in cough and cold and are used as antitussive agent ${ }^{30}$.

The frequency of cough of control group ranges between $74.0 \pm 0.012$ and $69.50 \pm 0.016$ (mean \pm S.E.M) and the frequency of cough of extract group ranges between $39.90 \pm 0.012$ and $7.70 \pm 0.026$ (mean \pm S.E.M). The antitussive effect was highly significant $(* * p<0.005)$ at 500 and $1000 \mathrm{mg} / \mathrm{kg}$, and non-significant at the dose of $300 \mathrm{mg} / \mathrm{kg}$. In the present study the extract of Mucuna pruriens after oral administration decrease the cough frequency similar to that of codeine phosphate. The effect of Mucuna pruriens administered at the highest doses caused a significant inhibition of cough reflex comparable to codeine phosphate $(10 \mathrm{mg} / \mathrm{kg})$. It has efficacious value in experimental cough and is widely available over-the-counter as a cough suppressant.

In another study asterosaponin has an expectorant, antitussive and anti-asthmatic effects and decreased the frequency of cough caused by ammonia in mice and asthma induced by histamine $^{31}$ and Mucuna pruriens contains flavonoids and saponin that are involve for the therapeutics of respiratory diseases and chronic bronchitis. So antitussive effect of herbal drug could be due to the effect of Mucuna pruriens's constituent flavonoid and saponin.

Mucuna pruriens may act directly on opioids receptors as codeine. Opioids receptors have multiple subtypes ${ }^{32}$ and codeine binds with mu $(\mu)$ receptor within CNS and alters the processes of emotional pain response by affecting the perception of pain. And Mucuna pruriens has an analgesic effect also. So Mucuna pruriens could be act on opioids or $\mathrm{mu}(\mu)$ receptor as codeine that may locate in tracheobronchial passage, produces inhibitory action on opioids.

It is concluded that the Mucuna pruriens is non-toxic and has a potential of centrally acting cough suppression and can be use safely as an anti-tussive agent.

\section{REFERENCES}

1. Abu-Rabia A. Urinary diseases and ethnobotany among pastoral nomada in the Middle East. J Ethnobiol Ethnomed. 2005; 1(4): 1-3.

2. Govaerts R. How many species of seed plants are there ? Taxon. 2001; 50: 1085-1090. http://dx.doi.org/10.2307/1224723

3. Strader D B, Seeff L B. Zakim and Boyer hepatology. T.D. Boyer, T.L. Wright,M.P. Manns Eds. Hepatotoxicity of herbal preparations (5th ed.), US Saunders - Elsevier, Philadelphia 2006; pp. 551-560.

4. Mothana, R.A. and Linclequist, V . Antimicrobial activity of some medicinal plants of the island Soqotra. J-Ethnopharmacei 2005; 96: 177181. http ://dx.doi.org/10.1016/j.jep.2004.09.006 PMid:15588668

5. Sheetal V and Singh S P. Current and future status of herbal medicines. Vet World. 2008; 1(11): 347-350.

6. Firenzuoli F and Gori L . Herbal medicine Today: Clinical and Research Issues. EBCAM. 2007; 4(Suppl 1): 37 - 40.

7. Parekh $\mathrm{J}$ and Chanda S. Antibacterial and phytochemical studies ontwelve species of Indian medicinal plants. AJBR. 2007; 10: 175 181.

8. Akindle A J andBusayo F I. Effects of the hydroethanolic extract of Mucuna pruriens (L.) DC (Fabaceae) on haematological profile in normal and haloperidol treated rats. Nig Q J Hosp Me. 2011; 21(2):93-8.

9. Parakash, Dhan, Niranjan, Abhiskek and Tewari. S K. Nutritional properties of Mucuna pruriens. Int J Food Sci Nutr.2001; 52: 79 - 82. http://dx.doi.org/10.1080/09637480020027264

10. Sathiyanarayanan L and Arulmozhi S. Mucuna pruriens Linn.A comprehensive review, Phog Rev. 2007; 1:157-162.
11. Rajeshwar Y, Gupta M, Kanti U and Mazumder. In Vitro Lipid Peroxidation and Antimicrobial Activity of Mucuna pruriens Seeds. IJPT. 2005; 4:32-35.

12. Manyam B V, Dhanasekaran M, Hare T A. Effect of antiparkinson drug HP- 200 (Mucuna pruriens) on the central monoaminergic neurotransmitters. Phytother Res. 2004a; 18:97-101. http:/ /dx.doi.org/10.1002/ptr.1407 PMid:15022157

13. Manyam BV, Dhanasekaran M, Hare T A. Neuroprotective effects of the antiparkinson drug Mucuna pruriens. Phytotherapy Res. 2004b; 18:706-712. http://dx.doi.org/10.1002/ptr.1514

14. Ahmed M K, Mahdi AA, Shukla KK, Islam N, Jaiswar S P and Ahmed S. Fertil Steril. Department of Biochemistry and Obstetrics and Gynecology. King George's Medical University, Lucknow, India. 2007.

15. Devi M S S and Kumar B S. Antifungal and Anthelmintic Activity of Extracts of Mucuna Pruriens Seeds. JPT. 2001; 1:4

16. Ekanem A P, Objekezie A, Kloas W, Knopf K. Effects of crude extracts of Mucuna pruriens (Fabaceae) and Carica papaya (Caricaceae) against the protozoan fish parasite Ichthyophthirius multifiliis. Parasitol Res. 2004; 92(5):361-366. http://dx.doi.org/10.1007/s00436-003-1038-8 PMid: 14735356

17. Rathi S S, Grover J K, Vats V. The effect of Momardica charantia and Mucuna pruriens in experimental diabetes and their effect on key metabolic enzymes involved in carbohydrate metabolism. Phytother Res.2002;16(8):774-777.http://dx.doi.org/10.1002/ptr.1064 PMid: 12458487

18. Tripathi Y B and Upadhyay A K. Antioxidant property of Mucuna pruriens Linn. Curr Sci. 2001; 80(11):1378.

19. Ratnawati H, Widowati W. Anticholesterol Activity of Velvet Bean (Mucuna pruriens L.) towards Hypercholesterolemic Rats. Sains Malaysiana. 2011; 40: 317-321.

20. Suresh S, Prithiviraj E, Prakash S. Dose- and time-dependent effects of ethanolic extract of Mucuna pruriens Linn. seed on sexual behaviour of normal male rats. J Ethnopharmacol. 2009; 122: 497-501. http:// dx.doi.org/10.1016/j.jep.2009.01.032 PMid:19429319

21. Bhaskar. A, Vidhya. V.G and Ramya. M. Hypoglycemic effect of Mucuna pruriens seedextract on normal and streptozotocin-diabetic rats. Fitoterapia. 2008; 79: 539-543. http://dx.doi.org/10.1016 /j.fitote.2008.05.008 PMid: 18672037

22. Guerranti R, Aguiyi J C, Neri S, Leoncini R, Pagani R and Marinello E. Proteins from Mucuna pruriens and enzymes from Echis carinatus venom: characterization and cross-reactions. J Biol Chem. 2002; 277(19):17072-17078. http://dx.doi.org/10.1074/jbc.M201387200 PMid: 11867642

23. Fung SY, Tan N H and Sim S M. "Protective effects of Mucuna pruriens seed extract pretreatment against cardiovascular and respiratory depressant effects of Calloselasma rhodostoma (Malayan pit viper) venom in rats," Trop Biomed. 2010; 27(3):366-372. PMid:21399576

24. Treanor J J, Hayden F G. Viral infections. In: Murray JF, ed. Textbook of respiratory medicine. 3d ed. Philadelphia: Saunders. 2000; 929-84.

25. Joshi S G. Medicinal Plants. Mohan Primlani for Oxford and BH Publishing Company (Pvt.) Ltd., 66 Jan Paths, New Delhi-110002, p.203.2000.

26. Miyagoshi A, Amagaya S and Ogihara Y. Antitussive effects of Lephedrine, amydalin and makyo kansekito (Chinese traditional medicines) using a cough model induced by sulfur dioxide gas in mice. Planta Medica. 1986; 52:275 - 278. http://dx.doi.org/10.1055/s-2007969151

27. Newman. D. "The distribution of range in samples from a normal population, expressed in terms of an independent estimate of standard deviation". Biometrika. 19369; 31 (1): 20-30.

28. Keuls M. "The use of the "studentized range" in connection with an analysis of variance". Euphytica. 1952; 1: 112-122. http://dx.doi.org/ 10.1007/BF01908269

29. Krishnan K S and Mary. The useful plants of India. National institute of Science communication. 2000. p. 383.

30. Joshi S J. Medicinal plants. Mohan Primlani for Oxford and B H publishing

31. Chenghua Guo, Xuexi Tang, Xinwei Dong and Yan Yang. Studies on the expectorant, antitussive and antiasthmatic properties of asterosaponin extracted from Luidia quinaria. African Journal of Biotechnology. 2009 ; 8 (23): 6694-6696.

32. Khandelwal Vinoth Kumar, Megraj K V K, Raju K, Balaraman R, Meenakshisundaram K. Biological Activities of Some Indian medicinal plants. JAPER. $2011 ; 1: 12-44$

\section{Cite this article as:}

Nuzhat Sultana, Rafeeq Alam Khan, Iqbal Azhar. Anti-tussive effect and gross toxicities of methanol extract of Mucuna pruriens (L) DC in comparison of codeine phosphate. Int. Res. J. Pharm. 2013; 4(6):62-65 